\title{
The Impact of the Rural Environment and Environmental Conservation on Poverty Alleviation: The Moderating Effect of Tourism Resources
}

(Impak Persekitaran Luar Bandar dan Pemuliharaan Alam Sekitar ke atas Pembasmian Kemiskinan: Kesan Sumber Pelancongan sebagai Moderator)

\author{
Komathi Wasudawan \\ (Faculty of Business, Design and Art, Swinburne University of Technology) \\ Rossazana Ab-Rahim \\ (Faculty of Economics and Business, Universiti Malaysia Sarawak)
}

\begin{abstract}
The rural environment adds value to the countryside that provides socio-economic development while environmental conservation draws attention to the locals protecting the environment from deforestation. In line with the Stakeholder Theory, this study examines the impact of the rural environment and environmental conservation on poverty alleviation; tourism resources are used as a moderator to measure the strength of endogenous and exogenous variables. Data was collected from 520 respondents in Kuching and Miri, Sarawak, Malaysia. Partial Least SquareStructural Equation Modelling (PLS-SEM) was used to analyse the hypotheses. The results of the study indicate that tourism contributes to an increase in the household income of locals; however, there is a negative relationship between rural environment, tourism resources and poverty alleviation due to the high cost of private transportation to the rural areas. The results imply that the improvement inaccessibility of public transportation to the rural areas would increase the use of tourism resources and tourist arrivals, and enhance the well-being of local communities. This study also contributes to the literature on rural environment, environmental conservation, tourism resources, poverty alleviation and Stakeholder Theory.
\end{abstract}

Keywords: Environmental impact; tourism resources; poverty alleviation; tourism development; stakeholder theory

\section{ABSTRAK}

Persekitaran luar bandar memberi nilai tambah sosio-ekonomi penduduk di kawasan desa, sementara pemuliharaan alam sekitar menarik perhatian penduduk tempatan dalam melindungi alam sekitar dari penebangan hutan. Selaras dengan teori pemangku kepentingan, kajian ini mengkaji kesan persekitaran luar bandar dan pemuliharaan alam sekitar terhadap pembasmian kemiskinan serta sumber pelancongan yang digunakan sebagai moderator untuk mengukur kekuatan pembolehubah endogen and eksogen. Data dikumpul daripada 520 responden dari Kuching dan Miri, Sarawak, Malaysia. Perisian PLS-SEM telah digunakan untuk menganalisis hasil hipotesis. Hasil kajian menunjukkan pelancongan menyumbang kepada penduduk tempatan dalam meningkatkan pendapatan isi rumah. Walaubagaimanapun, terdapat hubungan negatif terhadap pembasmian kemiskinan akibat kos pengangkutan swasta ke kawasan luar bandar adalah tinggi. Kajian ini memberi implikasi bahawa perkhidmatan pengangkutan awam ke kawasan luar bandar dapat meningkatkan penggunaan sumber pelancongan, ketibaan pelancong dan membasmi kemiskinan. Kajian ini juga memberi sumbangan kepada teori pemangku kepentingan dan kesusasteraan pro-miskin pelancongan. 
Kata kunci: Impak persekitaran; sumber pelancongan; pembasmian kemiskinan; pembangunan pelancongan; teori pemangku kepentingan

\section{INTRODUCTION}

Tourists travel to escape from their busy working schedules, and many choose to go to rural environs. Rural environs are often seen to be a tropical paradise, rich in flora, fauna, rivers, and forests as well as noted to be calm place. The rural environment is a resourceful solution to alleviate poverty. Uniqueness of the countryside in Sarawak, numerous types of tourism products have been created, which have contributed to household income (Naidoo \& Sharpley 2016). Recent figures (2015) show Sarawak to be covered by $79.2 \%$ of forest; there have been efforts towards environmental conservation and this has resulted in rural tourism, eco-tourism, and sustainable tourism development (State Planning Unit 2016). People travel for leisure, business or personal reasons, which in turn creates economic, social, and environmental interchange (Seers 1969).

Poverty means having earnings of less than US\$1.25 a day and being inaccessible to sources of energy, water supply, tarred roads, kitchen facilities, education, and healthcare (United Nations 2016; Hatta \& Ali 2013). Sarawak has a poverty rate of $0.5 \%$ in urban areas and 1.6\% in rural areas (Department of Statistics Malaysia 2015). The United Nations (UN) and the United Nations World Tourism Organisation (UNWTO) work towards assisting people who live on earnings of less than US $\$ 1.25$ a day through pro-poor tourism as the global tourism emerging economies is expected to reach $57 \%$ by 2030 from $45 \%$ in 2016 (United Nations 2016; United Nations Development Programme 2016; United World Tourism Organisation 2018). Pro-poor tourism is the positioning of tourism growth to produce livelihood opportunities between tourism and the poor (Ashley, Goodwin \& Roe 2001; Mowforth \& Munt 2016).

In addition to the rural environment and environmental conservation, tourism has a link to tourism resources. Tourism utilises tourism resources such as nature, rural, culture, wildlife and physical resource or caves owned by stakeholders to enhance poverty alleviation (Freeman 1983; Akama \& Kieti 2007; Barney, Ketchen \& Wright 2011). In this study, the local semigovernment and government departments, the private tourism organisations, and private tourism business channels (i.e., National Parks, accommodation providers, Sarawak Cultural Village, souvenir sellers, travel operators, food and beverage providers) and local communities are classified as stakeholders. As such, this study employs the Stakeholder Theory to justify the relationship of various organisations and individuals who are affected by the rural environment, environmental conservation and tourism resources on poverty alleviation. Tourism resources in the Stakeholder Theory concerns in managing resources, sustainable resource use, effective tourism planning, innovation, and resource diversification to determine the impact of the rural environment, environmental conservation and tourism resources in achieving poverty alleviation. Previous studies have not utilised the Stakeholder Theory in investigating the impact of the rural environment, environmental conservation and tourism resources on poverty alleviation.

Tourism resources variable obtained from several studies of Pakurar and Olah (2008), Satarat (2010), Mthembu (2011), Keovilay (2012), Miyakuni (2012), Mohamed (2013), Nitikasetsoontorn (2014) and Truong (2014) as an independent variable. However, this study looks at tourism resources as a formative moderator between the rural environment, environmental conservation, and poverty alleviation and this can contribute to addressing the research gap in this area. The remaining of this paper looks into theoretical and empirical studies on tourism resources and poverty alleviation as presented in Literature Review section 
followed by the Methodology section. The subsequent section presents the results and the discussion of the results while the Conclusion section offers a summary of the results as well policy implications.

\section{LITERATURE REVIEW}

Urbanisation and industrialisation have made people from the city appreciate the rural lifestyle, and thus choose to travel to rural destinations. Hence, the rural environment has created rural tourism. A study on rural tourism in Malaysia suggested that tourist satisfaction and loyalty to the rural environment can be enhanced with quality services by the local communities, which also improves the local businesses' profits and resilience (Osman \& Sentosa 2013; Amir et al. 2015). A longitudinal study focused on Bario in the Kelabit Highlands in Sarawak highlighted that tourism increases the creation of income via eco-tourism and cultural tourism (Lo, Cheuk \& Atang 2014). A study at the Setiu Wetland in Terengganu, on the east coast of Peninsular Malaysia found that the local population could generate income from tourism if there is an increase in tourist arrival to rural areas (Halim 2014). High homestay rates at Beng Village, the Lenggong Valley, tourists unlikely to recommend the homestay to others created a less monetary contribution to Beng Village from the tourism sector (Rasoolimanesh, Dahalan \& Jaafar 2016).

Rural environment in the Northern Great Plain Region, Hungary has attracted a significant number of tourists to the Hortobagy National Park. The Hortobagy National Park has ancient domestic animals, historical sites and villages as tourism products for tourists to enjoy (Pakurar \& Olah 2008). In Hungary, rural tourism started in 1990 when the government recognised that rural tourism adds revenue to the local economy (Kulcsar 2015). Rural tourism is outstandingly developed in Austria and France. In Austria, rural tourism businesses by local communities have received government subsidies and micro-loans to develop tourism businesses. In France, financial support from the government goes beyond financial support to the capacity building so that the local people can be involved in tourism development (Pakurar \& Olah 2008). The rural environment also creates gastronomy tourism which is closely related to sustainable rural tourism development. Gastronomy tourism connects the local food network with the rural environment, supports local food producers and lifts the locals' household income (Klytchnikova \& Dorosh 2013; Trihas, Kyriakaki \& Zagkotsi 2015). However, rural tourism has created shortages in food supply in Laos due to a large number of tourist arrivals in some impoverished villages (Ounmany 2014).

Environmental conservation has become a universal target in the world (Holden 2016; Brahmasrene \& Lee 2017). Environmental conservation means landscaping using indigenous plants, recycling waste materials, using renewable energy and grey water systems, and composting waste (Andereck 2009; Erdogan \& Tosun 2009; Han, Hsu \& Sheu 2010). The South Africa National Parks highlighted the need for waste management education, renewable energy sources, and eco-friendly products to help in conserving the environment (Plessis, Merwe \& Saayman 2013). In Africa, environmental deterioration has cause critical food insecurity or food poverty (Munanura et al. 2017). The National Parks in Malaysia have a negative impact on the environmental conservation even though eco-tourism has created job opportunities such as boatmen and tour guides (Ramachandran 2009). Anuar, Jaini, Robat and Jamaluddin (2018) studied environmental conservation and ecotourism agencies in Peninsular Malaysia. Their results show that ecotourism agencies rarely adopt any environmental policies in their management system. However, in Koh Phi (Thailand) and Gili Trawangan (Indonesia), development in tourism has made environmental conservation as practice (Dodds, Graci \& Holmes 2010). Therefore, over the years, the rapid growth in tourism has resulted in sustainable tourism development and responsible tourism. 
Environmentalists have started to question the sustainability of tourism development for environmental conservation (Sharpley 2000). As a result, social enterprises have achieved environmental conservation with a combination of strong leadership and market positioning on sustainable tourism development, responsible tourism (Vrasti 2013) and green hotels (Mbasera et al. 2016) to achieve socio-economic goals in developing countries (Barakagira \& Wit 2017). In recent years, concerns about environmental conservation have been raised among researchers, the public and private sectors, policymakers and NGOs in relation to poverty alleviation (Truong \& Hall 2017; West \& Haug 2017).

Resources are a dimension in the Stakeholder Theory as seen in relationships with various groups, organisations and individuals; who can be affected by any activities such as managing resources, effective tourism planning, product diversification and innovation to determine the impacts of tourism resources in achieving community well-being (Freeman 1984). People and resources are related closely to generate profitable business transactions and non-profitable transactions (Penrose 1959). Tourism development has a strong linkage between tourism resources, such as culture, natural landscapes, wildlife, rural attractions, agriculture, human beings, financial sources, climate, infrastructure, man-made and natural physical resources, and historical sites in operating tourism activities for tourists (Gursoy \& Rutherford 2004).

Tourism resources are unique resources because consumption happens at the place of production (Barney 1986). The scenario created at tourism destinations is more likely to have direct impact compared to other areas where product consumption takes place away from the destination of production (Duffield 1982). The development in tourism resources brings cash and non-cash benefits to the community operating these resources (Gholami, Assayesh \& Alipour-Nakhi 2010). Tourists travel to experience tourism resources in different places, while the local community uses tourism resources to earn a living (Ounmany 2014). In such a situation, the increasing number of tourist arrivals leads to an increase in household income for the local communities. Developing countries are blessed with tourism resources which can create wealth among the local people, such as the beaches in Costa Rica (Duim \& Caalders 2008), the tea heritage tourism in Sri Lanka (Aslam \& Jolliffe 2015), and cultural tourism in Mae Hong Son province of northern Thailand (Lacher \& Nepal 2010).

In this study, tourism resources are identified as a moderator because when tourism resources are utilised, the impact on the rural environment and environmental conservation increases, thus decreasing the poverty level. A moderator is an independent variable that creates a direction and/or strengthens the relation between an independent variable and the dependent variable (Barron \& Kenny 1986). Based on the above discussion, this study employed environmental conservation and rural environment as independent variables while poverty alleviation served as the dependent variable. (The list of items used to measure the variables are presented in the Appendix).

\section{THEORETICAL FRAMEWORK}

The Stakeholder Theory was introduced by Freeman (1983). Freeman defines that a phenomenon is characterised by its relationships with various groups, organisations, and individuals who are affected or can affect any activities or objectives of a company. The Stakeholder Theory also states as stakeholders must be satisfied in trade fairs; otherwise, they would fail to give support to policy implications, security, organisational progress, and community well-being. Donaldson and Preston (1995) defines Stakeholder Theory as stakeholders must have the same interest in the organisation. While, Crosby, Kelly and Schaefer (1986: 171) refines Stakeholder Theory as: 
"an effort to put a representative group of the public in dialogue with public officials so that the officials get the reactions of the public themselves on a particular subject"

Stakeholders involved in tourism development must economically benefit from the use of tourism resources such as culture, nature, wildlife, rural and physical equally in alleviating poverty. The diversity, rarity and uniqueness in tourism resources differ from one tourist destination to another. Different tourism businesses retain different tourism resources, innovations, and capabilities, as well as perform tourism activities based on resource variations (Barney 1991). By focusing on resources, the ability in utilising the tourism resources in tourism development creates various tourism products for the market (Alvarez \& Busenitz 2001), especially on pro-poor tourism which provides a neutral effect on profit gaining among the stakeholders. Thus, tourism channels should shift their focus from the powerful stakeholders to the local communities and engage in on-going two-way dialogue with local communities as stakeholders need an equal level of information to understand tourism resources in pro-poor tourism. The Stakeholder Theory emphasises the use of tourism resources to enhance local community participation in tourism. Therefore, the Stakeholder Theory is used as an underpinning theory to lead this study.

\section{CONCEPTUAL FRAMEWORK}

This study aims to examine the effects of the rural environment and environmental conservation on poverty alleviation and the moderator effect of tourism resources on the rural environment, environmental conservation and poverty alleviation (see Figure 1). Tourism resources are an independent variable. However, it is a moderator variable in this study to measure the relationship consistency between the independent and dependent variable. The variables in this study have been taken from previous studies: rural environment Satarat (2010) and Musinguzi (2012); environmental conservation Miyakuni (2012); tourism resources Nitikasetsoontorn (2014) and Truong (2014) and poverty alleviation Keovilay (2012) and Mohamed (2013). As a result, the following hypotheses were developed for this study:

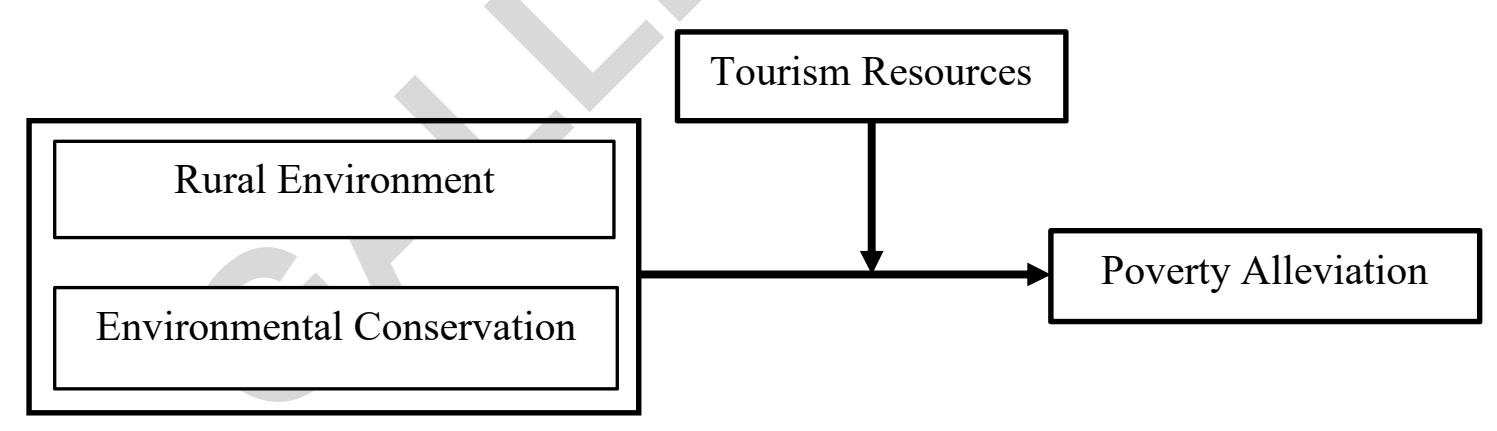

FIGURE 1. The conceptual framework

Source: Satarat (2010), Keovilay, (2012), Miyakuni (2012), Musinguzi (2012), Mohamed (2013) and Truong (2014).

\section{DEVELOPMENT OF HYPOTHESES}

Rural Environment and Poverty Alleviation The rural environment is a rich resourceful to increase household income among the local communities (Snyman 2014). The rural environment can create rural tourism, gastronomy tourism, farm tourism, geo-tourism and ecotourism to increase community well-being (Naidoo \& Sharpley 2016; Cao \& Yang 2019). A few studies in Malaysia, Uganda, and Panama show that the rural environment has contributed to poverty alleviation too (Pakurar \& Olah 2008; Osman \& Sentosa 2013; Kulcsar 2015). A 
study on homestay operators in rural areas, Malaysia found that rural tourism contributed to the community's well-being (Nair et al. 2015). The rural environment in Bigodi village, Uganda improved the agricultural market and generated income for the community (Lepp 2007). Further, farm tourism in Panama showed benefit to local food production, enhanced agricultural productivity and improved small-scale businesses among the local communities, entrepreneurs and government (Aslam \& Awang 2015). Thus, the Stakeholder Theory explains that the rural environment is an efficient way to increase household income and alleviate poverty. Hence, hypothesis $\mathrm{H}_{1}$ is formulated:

$\mathrm{H}_{1}$ There is a positive relationship between the rural environment and poverty alleviation.

Environmental Conservation and Poverty Alleviation Environmental conservation is a major concern in tourism. Tourism practitioners in areas such as eco-tourism, sustainable tourism development, and responsible tourism are more aware of environmental conservation and poverty alleviation (Holden 2013). A case study in the Great Limpopo, Zimbabwe noted that the Sengwe communities are aware of the potential role of environmental conservation towards tourism which provides employment and revenue opportunities for the local people (Chiutsi \& Saarinen 2017). Choosing tourism as a route to poverty alleviation helps in conserving the environment for the next generation (Holden 2016). A study on communitybased eco-tourism project in Laos showed in increased the community's well-being and improved their financial capital (Ounmany 2014). The Asian Development Bank, Lao Government, the Netherland Development Organisation (SNV) and private tourism enterprises also played a significant role in environmental conservation and poverty alleviation by introducing community-based eco-tourism projects (Harrison \& Schipani 2007). Therefore, environmental conservation is important in poverty alleviation. In addition, the Stakeholder Theory agrees that stakeholders can affect tourism activities for socio-economy benefits. Hence, hypothesis $\mathrm{H}_{2}$ is structured:

$\mathrm{H}_{2}$ There is a positive relationship between environmental conservation and poverty alleviation.

Tourism Resources Moderates the Relationship between the Impact on the Rural Environment and Poverty Alleviation While, tourism development highlights the use of tourism resources, the rural environment provides more tourism products such as rural sports tourism, traditional spas, village tourism, and eco-museums. In Hungary, the rural environment has a positive relationship with the utilisation of tourism resources in generating tourism employment and income (Pakurar \& Olah 2008). In addition, the Community-Based Natural Resource Management program in Botswana shows that the rural environment covers basic needs such as shelter, employment, income, water supply, transportation, scholarships and funeral expenses of local communities (Mbaiwa \& Stronza 2010). Similarly, in Greek and Hungarian rural environment aspects such as nature, mountain areas, rivers, lakes plants, and wildlife are used to encourage rural tourism for sustainable development (Fotiadis 2009). Therefore, tourism resources are used to measure the strength of the relationship between the rural environment and alleviating poverty. Raising the income and living standards of the local communities with the use of tourism resources is supported by the Stakeholder Theory. Hence, the hypothesis $\mathrm{H}_{3}$ is structured:

$\mathrm{H}_{3}$ Tourism resources moderate the relationship between the rural environment and poverty alleviation. 
Tourism Resources Moderate the Relationship between the Impact of Environmental Conservation and Poverty Alleviation Higher rates of urbanisation and industrialisation have negative impacts on the environment (Brahmasrene \& Lee 2017). Therefore, environmental conservation is needed in tourism to protect the environment and to achieve socio-economic development in developing countries (Barakagira \& Wit 2017). Hence, ecotourism, sustainable tourism development, and responsible tourism contribute to environmental conservation and creates economic benefits for the local people through the collection of admission fees at entrances. Such tourism decreases climate change and environmental damage which can lead to poverty (Okazaki 2008). In Nicaragua the utilisation of natural tourism resources supports poverty alleviation, employment opportunities, environmental conservation and creates participatory opportunities from other economic sectors (Croes \& Vanegas 2008). The integration of environmental conservation and the use of tourism resources have also led to poverty alleviation. It is explained in the Stakeholder Theory (Ashley \& Carney 1999). Hence, the hypothesis $\mathrm{H}_{4}$ is structured:

$\mathrm{H}_{4}$ Tourism resources moderate the relationship between environmental conservation and poverty alleviation.

\section{METHODOLOGY}

Kuching and Miri were selected as research areas for having the highest population and tourist arrivals in Sarawak. Convenience sampling is often used in exploratory research and is the best way of getting information quickly, efficiently and cheaply (Sekaran \& Bougie 2003). Hence, convenience sampling was used in selecting the respondents. The researcher sampled 364 respondents; however, 260 questionnaires were used to run the analysis. These 260 questionnaires were from the Samajaya Natural National Park (9 respondents), Semenggoh Nature Reserve (16 respondents), Kubah National Park (11 respondents), Santubong National Park (3 respondents), Fairy and Wind Caves (8 respondents), Gunung Gading National Park (16 respondents), Annah Rais Homestay (7 respondents), Santubong Village Homestay (3 respondents), Tanah Hitam Village Homestay (8 respondents), Pueh Village Homestay (9 respondents), Sarawak Cultural Village (68 respondents), Souvenir Sellers (3 respondents), Travel Operators (24 respondents), Damai Puri Resort \& Spa (6 respondents), Damai Beach Resort (11 respondents), Palm Beach Resort (8 respondents), The Nomad Resort (9 respondents), Hotel United Yes Retreat (14 respondents), Bunker bed and breakfast (1 respondent), Jong's Crocodile Park (15 respondents) and Food and Beverage Providers such as Warisan Layer Cake House (3 respondents) and Mira Layer Cake Factory (8 respondents).

The study further sampled 316 respondents and used 260 questionnaires for analysis. Those questionnaires were from the Niah Cave National Park (17 respondents), Mulu National Park (69 respondents), Homestay Kedayan (5 respondents), Rumah Patrick Homestay (15 respondents), Travel Operator (5 respondents), Miri Merit Hotel (21 respondents), Miri Park City (34 respondents), Miri Marriot Hotel (53 respondents) and Mulu Marriot Hotel (41 respondents). A total of 520 questionnaires were analysed in this study; 162 questionnaires were discarded as they were not completed, filled or returned. $G^{*}$ Power analysis was conducted using $\mathrm{G}^{*}$ Power 3.1 software (Faul et al. 2009) by using the following parameters of the power (1- $\beta$ err probability of 0.95 ), an alpha significance level ( $\alpha$ err probability of 0.05 ), the effect size $\mathrm{f}^{2}(0.15)$ and 5 tested variables $(3$ independent variables and 2 moderator interactions). The analysis shows that a total sample of 92 is required to test the regression model (Cohen 1992; Faul et al 2009). However, for moderator testing, a larger sample size is required for significant findings. Hence, a total of 680 questionnaires was distributed in this 
study (Yamane 1967). A quantitative research design based on the Likert-scale was used to collect data and the items were adapted from past studies (see Appendix).

\section{RESULTS AND DISCUSSION}

\section{ASSESSMENT OF THE MEASUREMENT MODEL}

The measurement model was used to examine the loadings, composite reliability (CR), average variance extracted (AVE) and discriminant validity. The loading value for the rural environment $(0.683-0.780)$; environmental conservation $(0.628-0.772)$ and poverty alleviation (0.708 - 0.747) (see Table 1); the correlation of 35 indicators loading exceeded the recommended value of 0.5 . But, the item of PA09 was deleted for having the lower loading of 0.499 (Hair, Anderson, Babin \& Black 2010). The indicators for tourism resources (formative) construct gave the weight range of (-0.084 - 0.362). The internal consistency and individual indicator reliability were measured with the CR. The threshold point was 0.7 and above. In this study, the CR values were highly reliable for the rural environment $(0.890)$, environmental conservation (0.893), and poverty alleviation (0.900) (Hair et al. 2006). The AVE is to evaluate the convergent validity at a threshold value above 0.5 . The rural environment $(0.537)$, environmental conservation (0.511) and poverty alleviation (0.529) values were higher than 0.50 which explains the variance of indicators on average. Overall, convergent validity was achieved in this study (see Table 1) (Hair et al. 2014).

TABLE 1. Result of the measurement model

\begin{tabular}{lccccc}
\hline Variable & Item & Loading/Weight & CR & AVE & Measure \\
\hline Rural environment & RE1-RE7 & $0.683-0.780$ & 0.890 & 0.537 & Reflective \\
$\begin{array}{l}\text { Environmental } \\
\text { conservation }\end{array}$ & EC1-EC8 & $0.628-0.772$ & 0.893 & 0.511 & Reflective \\
$\begin{array}{l}\text { Tourism resources } \\
\text { Poverty alleviation }\end{array}$ & TR1-TR12 & $-0.084-0.362$ & SIM & SIM & Formative \\
\hline Pover-PA08 & PA0.708-0.747 & 0.900 & 0.529 & Reflective \\
\hline
\end{tabular}

Note: PA09 are deleted due to low loading of 0.4999

\section{DISCRIMINANT VALIDITY}

The square root values of each construct were compared. The AVE should be greater than any other construct (Chin 2010). The square root of AVE in this study was the rural environment (0.733), environmental conservation $(0.715)$ and poverty alleviation (0.727). Therefore, discriminant validity was achieved (see Table 2 ).

TABLE 2. Discriminant validity of measurement model

\begin{tabular}{lcccc}
\hline & EC & PA & RE & TR \\
\hline EC & $\mathbf{0 . 7 1 5}$ & & & \\
PA & 0.496 & $\mathbf{0 . 7 2 7}$ & & \\
RE & 0.492 & 0.560 & $\mathbf{0 . 7 3 3}$ & N/A \\
TR & 0.510 & 0.609 & 0.567 & \\
\hline
\end{tabular}

\section{ASSESSMENT OF THE STRUCTURAL MODEL ANALYSIS}

Figure 2 shows the results of hypotheses testing (t-value). The results of this study support the environmental impact of the rural environment $\left(\mathrm{H}_{1}\right)$ and environmental conservation $\left(\mathrm{H}_{2}\right)$ on poverty alleviation. The finding shows a weaker relationship between tourism resources and rural environment $\left(\mathrm{H}_{3}\right)$ on poverty alleviation. Tourism resources and environmental conservation $\left(\mathrm{H}_{4}\right)$ have a stronger relationship with poverty alleviation (see Figure 2 ). 


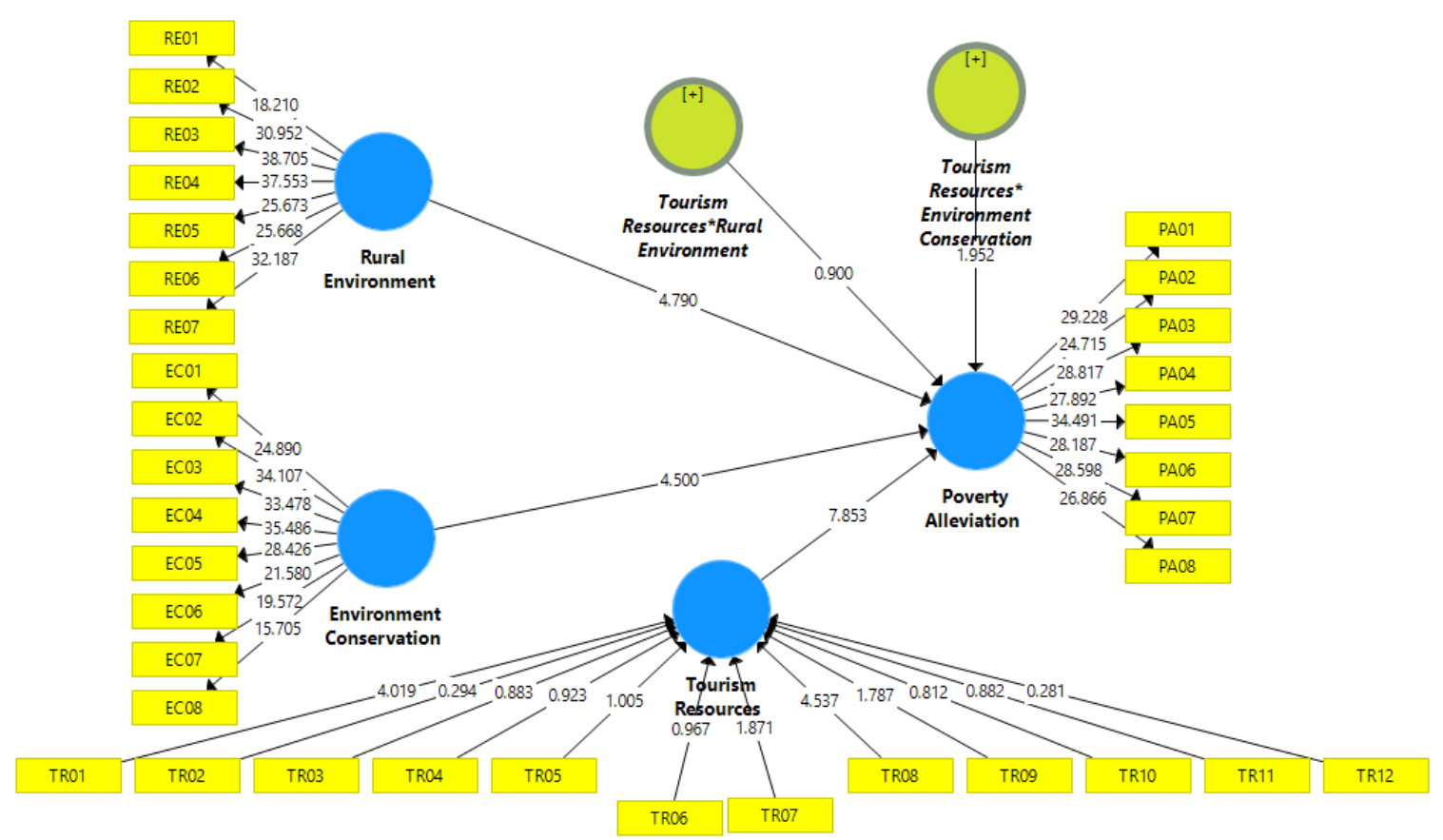

FIGURE 2. Results of the structural model

\section{HYPOTHESIS TESTING}

$\mathrm{H}_{1} \quad$ There is a positive relationship between the rural environment and poverty alleviation.

The results of Hypothesis 1 show a positive relationship between the rural environment and poverty alleviation $(\beta=0.264$, $t$-value $=4.790)$. The rural environment raises the development of gastronomy tourism and eco-tourism according to past studies and contributes to the household income (Pusiran \& Xiao 2013; Naidoo \& Sharpley 2016; Cao \& Yang 2019). The rural environment generates some diverse agricultural products for the tourism sector, and one of that is gastronomy tourism. Gastronomy tourism connects the local food network with the rural environment and lifts the locals' economic status or household incomes (Trihas et al 2015).

'Pesta Nukenen' or Food and Cultural Festival is annually celebrated in a rural environs in the month of July in Miri among the Kelabit ethnic group. The highlight of the Festival is the traditional delicacies served in bamboo and leaves produced from the farm and forest. Prepared using fresh organic ingredients, rice wrapped in leaves, bamboo chicken with tapioca leaves, local river fish rice porridge and pineapples are among the types of traditional food served in the Food and Cultural Festival. Besides, the Miri Country Music Fest was introduced in 2015 to promote the Food and Cultural Festival. Miri Country Music Fest is combination of musicians from the United States of America, Australia, Czech Republic, Indonesia, Singapore, Kota Kinabalu and Kuala Lumpur who entertain tourists with local folk country music in Miri.

In line with eco-tourism, Semenggoh Nature Reserve and Sarawak Biodiversity Centre have recently opened an Ecology and Discovery Trail. The Trail as a new tourism product involves identifying plants that produce different types of scents (Borneo Talk 2017). Meanwhile, tourism activities such as the Padawan Raft Safari, Bau Blue Lake Festival, Regatta race, and Siniawan and Sematan festivals are created along the rivers in Kuching. One of the possible pull factors behind the trail, raft safari, regatta, and festivals could be the rural environment. The result implies that the different tourism products obtained from the rural environment has increasingly been perceived as a potential to contribute to community wellbeing. Hence it can be concluded that Hypothesis 1 shows a positive result. It is noteworthy that the results of this study are also consistent with the Stakeholder Theory which states that 
stakeholders must be satisfied in business activities for socio-economic enhancement (Freeman 1983; Alvarez \& Busenitz 2001) (see Table 3).

$\mathrm{H}_{2}$ There is a positive relationship between environmental conservation and poverty alleviation.

The result of Hypothesis 2 indicates that environmental conservation is positively significant in alleviating poverty $(\beta=0.178, \mathrm{t}$-value $=4.500)$. Modernisation, industrialisation, and urbanisation have a negative impact on the environment (Hiltunen, Pitkanen \& Halseth 2016). Therefore, environmental conservation addressed by researchers, policymakers and NGOs in alleviating poverty (Holden 2013). Erdogan and Tosun (2009) and Han et al (2010) have mentioned that environmental conservation introduced in responsible tourism, rural tourism, sustainable tourism, and eco-tourism can encourage tourists to protect the environment.

The finding is in line with past empirical studies such as Holden (2016), Chiutsi and Saarinen (2017) as well as Ounmany (2014).The mentioned studies recommend that the rural tourism, village tourism and farm tourism are the best practices in alleviating poverty. It is important to highlight that the Sarawak Forestry Corporation is enthusiastic in protecting the forests by preserving existing national parks such as Semenggoh Nature Reserve, Samajaya National Park, Kubah National Park, Santubong National Park, Gunung Gading National Park, Fairy Cave, Wind Cave, Niah Cave and Mulu National Park for environmental conservation. For instance, the launch of the Ecology and Discovery trails by the Sarawak Biodiversity Centre has benefited the employment and revenue opportunities for the local communities.

The finding is consistent with the Stakeholder Theory as stakeholders have the same interest in preserving the environment (Barney 1991). The positive result of this study highlights that the local communities and the government in Sarawak are aware of the importance of environmental conservation for future generations to live without poverty. The Stakeholder Theory also views that environmental conservation creates small-scale communities or eco-businesses and alleviates poverty (Jamal \& Gets 1995). This is supported by Li (2004) and Spenceley (2005) who stated that the environmental conservation tourism activities are the best practice in pro-poor tourism strategies.

TABLE 3. Path coefficients and hypothesis testing

\begin{tabular}{|c|c|c|c|c|}
\hline Hypothesis & Relationship & Beta & t-value & Supported \\
\hline $\mathrm{H}_{1}$ & Rural environment $\rightarrow$ Poverty alleviation & 0.264 & $4.790 * *$ & Yes \\
\hline $\mathrm{H}_{2}$ & $\begin{array}{l}\text { Environmental conservation } \rightarrow \text { Poverty } \\
\text { alleviation }\end{array}$ & 0.178 & $4.500 * *$ & Yes \\
\hline
\end{tabular}

$\mathrm{H}_{3}$ Tourism resources moderate the relationship on the rural environment and poverty alleviation.

Hypothesis 3 tested the moderating effect of tourism resources between the rural environment and poverty alleviation. The result shows a weaker moderating effect of tourism resources between rural environment and poverty alleviation $(\beta=0.008$, t-value $=0.900)$. The study results conflict with the findings of Mbaiwa and Stronza (2010), Fotiadis (2009) and Pakurar and Olah (2008). Tourism resources are perhaps not completely utilised in Padawan, Bau, Lundu, Sematan, and Marudi compared to Mulu and Bario by the local communities, government, and private tourism channels. The first factor that contributes to the utilisation of tourism resources in Mulu and Bario is probably the easy access through flights by tourists. 
The second factor is probably the competition from tourism destinations in Kuching and Miri cities. It may reduce the opportunity for rural environments such as Padawan, Bau, Lundu, Sematan, and Marudi. Cities are easier for tourists to access, and this also saves on transportation costs. Therefore, improved public transportation services in a rural environment for equal profit distribution should be implemented. This suggestion is in line with Briedenhann and Wickens (2004), who said that the expansion of rural infrastructure increases tourist arrivals and achieves poverty alleviation. Therefore, the use of tourism resources in the rural environment has no impact on the livelihood of the local people in Sarawak, and Hypothesis 3 is not supported (see Table 4).

Using the tourism resources in a rural environment can be achieved by practising Butler's tourism destination life cycle. A tourist destination life cycle model has different stages such as exploration, involvement, development, consolidation, stagnation and rejuvenation. Applying Butler's tourist destination life cycle creates more tourism activities to attract more tourists and creates more businesses with the use of tourism resources especially in the Wind Cave, Fairy Cave and Blue Lake, Bau. The use of tourism resources in a rural environment also measures the importance of destination branding (Huibin, Marzuki \& Kostopoulou 2016). Therefore, the re-branding in a rural environment as a tourism destination can be a great influence in promoting the use of tourism resources at rural environment for socio-economic benefits, especially in the Wind Cave, Fairy Cave and Blue Lake, Bau.

$\mathrm{H}_{4}$ Tourism resources moderate the relationship between environmental conservation and poverty alleviation.

Hypothesis 4 tested the moderating effect of tourism resources between environmental conservation and poverty alleviation. The effect of environmental conservation on poverty alleviation is stronger than tourism resources $(\beta=0.003$, $t$-value $=1.952)$ (see Table 4$)$. The finding is in line with the Stakeholder Theory which states that the stakeholder utilises tourism resources equally to achieve environmental conservation and poverty alleviation. For example, Samajaya National Park, Semenggoh Nature Reserve, Kubah National Park, Santubong National Park, Gunung Gading National Park, Fairy Cave, Wind Cave, and Niah Cave may be utilising and preserving the tourism resources to generate an income. In Miri, the Mulu National Park is listed under UNESCO as a world heritage site; UNESCO also encourages local preservation of tourism resources such as plants, insects and animals.

Sarawak's forests are rich in flora that produce beautiful scent from latex and barks. For example, the 'Normah Orchid' which is found in Sarawak produces vanilla fragrance and Coelogyne asperata produces sweet aroma. The 'Selukai' and lemon grass are recognised as insect repellent, while cinnamon is used in cooking. These plants are used by the local people for medical, culinary and ritual purposes. The resources from the forest probably have motivated the Sarawak Forestry Corporation and Sarawak Biodiversity Centre to conserve the environment and generate household income. Moreover, the United Nations World Tourism Organisation (2013) also advocates sustainable tourism development by preserving the natural assets of tourist destinations across the world for poverty alleviation. Thus, the study also recommends the sustainable use of tourism resources because this enhances environmental conservation and poverty alleviation. The interaction plot below explains that the relationship is positive with a high-level use of tourism resources for environmental conservation and poverty alleviation (see Figure 3 ). 


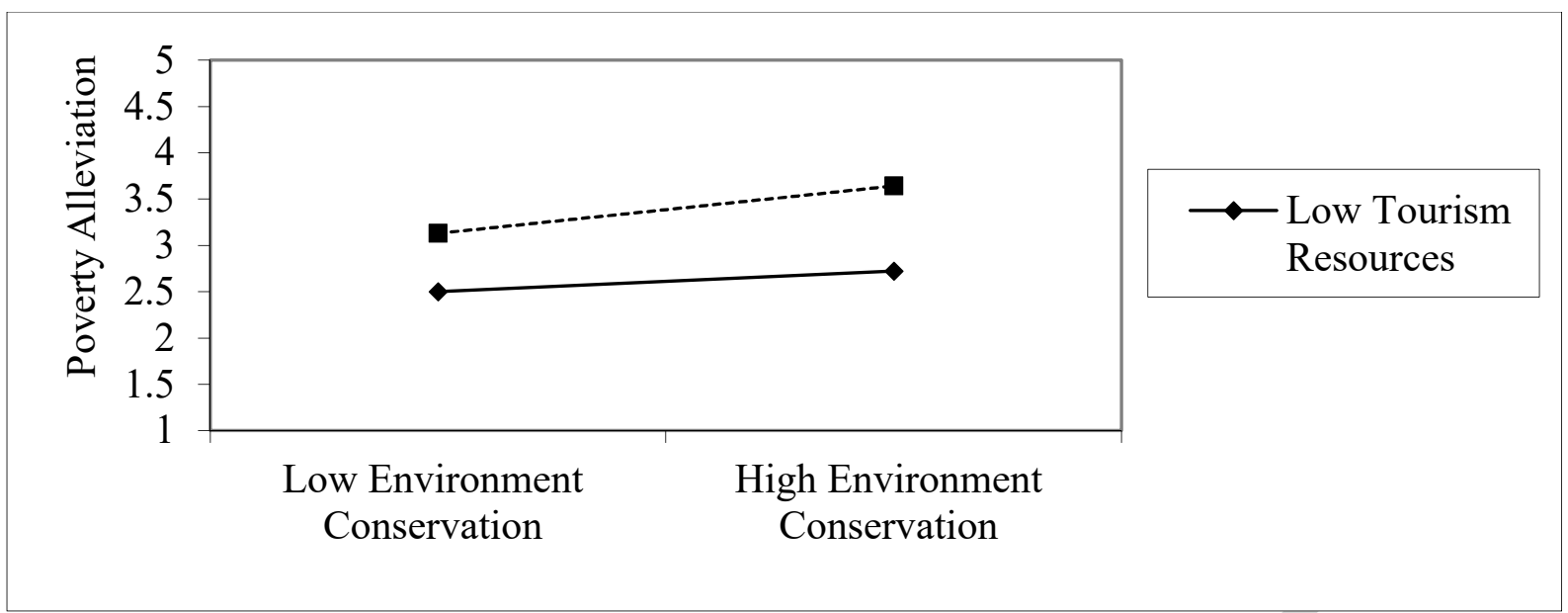

FIGURE 3. The interaction effect of tourism resources between environmental conservation and poverty alleviation

TABLE 4. Path coefficients and hypothesis testing

\begin{tabular}{llccc}
\hline Hypothesis & \multicolumn{1}{c}{ Relationship } & Beta & t-value & Supported \\
\hline $\mathrm{H} 3$ & $\begin{array}{l}\text { Rural environment*Tourism } \\
\text { resources } \rightarrow \text { Poverty alleviation }\end{array}$ & 0.040 & 0.900 & No \\
\hline $\mathrm{H} 4$ & $\begin{array}{l}\text { Environmental conservation*Tourism } \\
\text { resources } \rightarrow \text { Poverty alleviation }\end{array}$ & 0.072 & $1.952^{*}$ & Yes \\
\hline Note: ${ }^{*} \mathrm{p}<0.05$, t-value greater than $1.645-2.32$ (1 tailed) \\
$* * \mathrm{p}<0.01, \mathrm{t}$-value greater than 2.33 ( 1 tailed)
\end{tabular}

\section{COEFFICIENTS OF DETERMINATION $\left(\mathrm{R}^{2}\right)$}

Table 5 explains the model's predictive accuracy with and without the interaction effects of tourism resources. The model's predictive accuracy without tourism resources for poverty alleviation is at $0.460(46 \%)$ and with tourism resources is at $0.472(47 \%)$ (see Table 5). The rule of thumb for the acceptable coefficient of determination (R2) is 0.67 (substantial), 0.33 (moderate) and 0.19 (weak) (Hair et al 2014). The variance range of poverty alleviation is at a moderate level for the rural environment and environmental conservation on poverty alleviation with the interaction effect of tourism resources.

TABLE 5. Coefficient of determination $\left(\mathrm{R}^{2}\right)$ on poverty alleviation with and without interaction effect

\begin{tabular}{lcc}
\hline Endogenous Construct & \multicolumn{2}{c}{$\mathrm{R}^{2}$ Variance } \\
\cline { 2 - 3 } & With Interaction Effect & Without Interaction Effect \\
\hline Poverty Alleviation & 0.472 & 0.460 \\
\hline
\end{tabular}

\section{MANAGERIAL IMPLICATIONS}

This study emphasises that through collaboration, cooperation and tourism planning, local communities, the local government, private tourism organisations, semi-governmental tourism channels (e.g., National Parks, Jong's Crocodile Park, accommodation providers, Sarawak Cultural Village, souvenir sellers, travel operators, food and beverage providers) may create an equitable use of tourism resources to alleviate poverty. The local government, the private tourism organisations, semi-governmental tourism channels should shift their focus to the local communities' capabilities and engage in a two-way and on-going dialogue with local communities as stakeholders need an equal level of information to understand tourism resources in the rural environment. Tourism businesses are recommended to learn new technological skills and develop capacity building to combine with the current capabilities and 
technological innovations to generate sustainable competitive advantages over other countries as well as emphasise conserving, preserving and sustaining the tourism resources for future generations.

\section{CONCLUSION}

The study investigated the impacts of a rural environmental and environmental conservation on poverty alleviation with the moderating effect of tourism resources as a formative variable. This study was supported by the Stakeholder Theory. The Stakeholder Theory describes people's relationships with resources to create economic benefits from any business. Hence, the goal of the collaboration is to balance the power between all stakeholders in utilising tourism resources. A collaboration by a group of stakeholders to address a specific issue instead of focusing on one organisation is effective. Therefore, this study emphasises collaboration among local communities, local governments, private tourism organisations, semigovernmental tourism channels (e.g., National Parks, Jong's Crocodile Park, accommodation providers, Sarawak Cultural Village, souvenir sellers, travel operators, food and beverage providers) to create an equal use of tourism resources, especially in a rural environment. This is the first time that the effect of tourism resources as a formative moderator has been examined on a rural environment, environmental conservation and poverty alleviation. Most previous studies examined the effect of tourism resources as an independent variable. In conclusion, the current study provides significant theoretical contributions to the literature on tourism resources and to the Stakeholder Theory.

The study did not look into poverty alleviation factors from the non-tourism sector. Therefore, the future researcher could consider a comparative study between the tourism sector and non-tourism sectors to measure the socio-economic circumstance, especially in agricultural, and oil and gas industries in Sarawak.

\section{ACKNOWLEDGEMENT}

This work was supported by Ministry of Higher Education and Universiti Malaysia Sarawak [grant numbers F01/FRGS/1607/2017].

\section{REFERENCES}

Akama, J.S. \& Kieti, D. 2007. Tourism and socio-economic development in developing countries: A case study of Mombasa Resort in Kenya. Journal of Sustainable Tourism 15(6): 735-748.

Alvarez, S.A. \& Busenitz, L.W. 2001. The entrepreneurship of resource-based theory. Journal of Management 27(6): 755-775.

Amir, A.F., Ghapar, A.A., Jamal, S.A. \& Ahmad, K.N. 2015. Sustainable tourism development: A study on community resilience for rural tourism in Malaysia. Procedia Social and Behavioral Sciences 168: 116-122.

Andereck, K.L. 2009. Tourists' perceptions of environmentally responsible innovations at tourism businesses. Journal of Sustainable Tourism 17(4): 489-499.

Anuar, A.N.A., Jaini, N., Robat, M. \& Jamaluddin, E.R. 2018. The identification of criteria for ecotourism practice in Peninsular Malaysia. J Hotel Bus Manage 8(190): 2169-0286.

Ashley, C. \& Carney, D. 1999. Sustainable Livelihoods: Lessons from Early Experience. 1st edition. United Kingdom: Department for International Development. 
Ashley, C., Goodwin, H. \& Roe, D. 2001. Pro-poor tourism strategies: Making tourism work for the poor. Available at https://www.odi.org/sites/odi.org.uk/files/odiassets/publications-opinion-files/3246.pdf

Aslam, M.S.M. \& Awang, K.W. 2015. Enterprising rural tourism for sustainable rural development in Sri Lanka. International Journal of Economics and Financial Issues 5(1): 27-33.

Aslam, M.S.M. \& Jolliffe, L. 2015. Repurposing colonial tea heritage through historic lodging. Journal of Heritage Tourism 10(2): 111-128.

Barakagira, A. \& Wit, D.A.H. 2017. Community livelihood activities as key determinants for community based conservation of wetlands in Uganda. Environmental and Socioeconomic Studies 5(1): 11-24.

Barney, J.B. 1986. Strategic factor markets: Expectations, luck, and business strategy. Management Science 32(10): 1231-1241.

Barney, J.B. 1991. Firm resources and sustained competitive advantage. Journal of Management 17(1): 99-120.

Barney, J.B., Ketchen Jr, D.J. \& Wright, M. 2011. The future of resource-based theory: Revitalization or decline? Journal of Management 37(5): 1299-1315.

Baron, R.M. \& Kenny, D.A. 1986. The moderator mediator variable distinction in social psychological research: Conceptual, strategic, and statistical considerations. Journal of Personality and Social Psychology 51(6): 1173-1182.

Borneo Talk, 2017. A Scented trail: A delight for your olfactory senses. Available at http://www.borneotalk.com/e-magazine/\#1526909718146-ff333ff2-6c9b

Brahmasrene, T. \& Lee, J.W. 2017. Assessing the dynamic impact of tourism, industrialization, urbanization, and globalization on growth and environment in Southeast Asia. International Journal of Sustainable Development \& World Ecology 24(4): 362-371.

Briedenhann, J. \& Wickens, E. 2004. Rural tourism meeting the challenges of the new South Africa. International Journal of Tourism Research 6(3): 189-203.

Cao, X., \& Yang, Y. 2019. Rural tourism " new villagers" makers under the guidance of "homesickness" - Rural tourism entrepreneurship motivation model based on grounded theory. Paper presented at the 5th International Conference on Economics, Management and Humanities Science (ECOMHS 2019), 16 - 17 March, Bangkok, Thailand.

Chin, W. 2010. How to write up and report PLS analyses. In Handbook of Partial Least Squares, edited by V.V. Esposito, W.W. Chin, J. Henseler \& H. Wang, 655-690. Heidelberg: Springer.

Chiutsi, S., \& Saarinen, J. 2017. Local participation in transfrontier tourism: Case of Sengwe community in Great Limpopo Transfrontier Conservation Area, Zimbabwe. Development Southern Africa 34(3): 260-275.

Cohen, J. 1992. A power primer. Psychological Bulletin 112: 155-159.

Croes, R. \& Vanegas, M. 2008. Cointegration and causality between tourism and poverty reduction. Journal of Travel Research 47(1): 94-103.

Crosby, N., Kelly, J.M. \& Schaefer, P. 1986. Citizens panels: A new approach to citizen participation. Public Administration Review 46(2): 170-178.

Department of Statistic, Malaysia. 2015. Household Income and Basic Amenities Survey Report, 2014. Putrajaya, Malaysia: Department of Statistic.

Dodds, R., Graci, S. R., \& Holmes, M. 2010. Does the tourist care? A comparison of tourists in Koh Phi, Thailand and Gili Trawangan, Indonesia. Journal of Sustainable Tourism 18(2): 207-222.

Donaldson, T. \& Preston L. E. 1995. The Stakeholder Theory of the corporation: Concepts, evidence, and implications. Academy of Management Review 20(1): 65-91. 
Duffield, B.S. 1982. Tourism: The measurement of economic and social impact. Tourism Management 3(4): 248-255.

Duim, V.V.D., \& Caalders, J.D.A.D. 2008. Tourism chains and pro-poor tourism development: An actor-network analysis of a pilot project in Costa Rica. Current Issues in Tourism 11(2): 109-125.

Erdogan, N. \& Tosun, C. 2009. Environmental performance of tourism accommodations in the protected areas: Case of Goreme Historical National Park. International Journal of Hospitality Management 28(3): 406-414.

Faul, F., Erdfelder, E., Buchner, A. \& Lang, A.G. 2009. Statistical power analyses using G*Power 3.1: Tests for correlation and regression analyses. Behavior Research Methods 41: 1149-1160.

Faulkner, B. \& Tideswell, C. 1997. A framework for monitoring community impacts of tourism. Journal of Sustainable Tourism 5(1): 3-28.

Fotiadis, A. 2009. The role of tourism in rural development through a comparative analysis of a Greek and a Hungarian rural tourism area. Doctoral Dissertation, University of Pecs, Pecs, Hungary.

Freeman, R.E. 1983. Strategic management: A stakeholder approach. Advances in Strategic Management 1(1): 31-60.

Gholami, S., Assayesh, H., \& Alipour-Nakhi, A. 2010. The study of tourism geography in rural areas of Noushahr City of Mazandaran Province (Iran): The case of Balade Kojour Vill. American Eurasian Journal of Agricultural and Environmental Science 7(3): 341-346.

Gursoy, D. \& Rutherford, D.G. 2004. Host attitudes toward tourism: An improved structural model. Annals of Tourism Research 31(3): 495-516.

Hair, J.F., Anderson, R.E., Babin, B.J. \& Black, W.C. 2010. Multivariate Data Analysis: A Global Perspective. 7th edition. New Jersey: Pearson.

Hair, J.F., Black, W.C., Babin, B.J., Anderson, R.E. \& Tatham, R.L. 2006. Multivariate Data Analysis. 6th edition. New Jeysey: Pearson and Prentice Hall.

Hair, J.F., Hult, G.T.M., Ringle, C. \& Sarstedt, M. 2014. A Primer on Partial Least Squares Structural Equation Modeling (PLS-SEM). 1st edition. Unites States: Sage Publications.

Halim, N.A. 2014. Tourism as a tool for poverty alleviation using value chain analysis: A case study of Setiu Wetland, Terengganu, Malaysia. Doctoral dissertation, University of Tasmania.

Han, H., Hsu, L. \& Sheu, C. 2010. Application of the theory of planned behaviour to green hotel choice: Testing the effect of environment-friendly activities. Tourism Management 31(3): 325-334.

Harrison, D. \& Schipani, S. 2007. Lao tourism and poverty alleviation: Community-based tourism and the private sector. Current Issues in Tourism 10(3): 194-230.

Hatta, Z.A. \& Ali, I. 2013. Poverty reduction policies in Malaysia: Trends, strategies and challenges. Asian Culture and History 5(2): 48-56.

Hiltunen, M.J., Pitkanen, K. \& Halseth, G. 2016. Environmental perceptions of second home tourism impacts in Finland. Local Environment 21(10): 1198-1214.

Holden, A. 2013. Tourism, Poverty and Development. 1st edition. United Kingdom: Routledge.

Holden, A. 2016. Environment and Tourism. 3rd edition. United Kingdom: Routledge.

Huibin, X., Marzuki, A. \& Kostopoulou, S. 2016. Destination brand building of cultural heritage tourism. In: Opportunities and Challenges for Tourism and Hospitality in the BRIC Nations, edited by M.C. Dhiman, 175-190. Pennsylvania, United States: IGI Global.

Jamal, T.B. \& Getz, D. 1995. Collaboration theory and community tourism planning. Annals of Tourism Research 22(1): 186-204.

Keovilay, T. 2012. A case study of Luang Namtha Province Lao PDR. Doctoral Dissertation, Lincoln University, Lincoln, New Zealand.

Klytchnikova, I. \& Dorosh, P. 2013. Tourism sector in Panama: Regional economic impacts 
and the potential to benefit the poor. The World Bank 37(2): 70-79.

Kulcsar, N. 2015. Consumer value dimensions of rural tourism in Hungary. Hungarian Geographical Bulletin 64(2): 127-137.

Lacher, R.G. \& Nepal, S.K. 2010. From leakages to linkages: Local level strategies for capturing tourism revenue in Northern Thailand. Tourism Geographies 12(1): 77-99.

Lepp, A. 2007. Residents' attitudes towards tourism in Bigodi village, Uganda.Tourism Management 28(3): 876-885.

Li, W. 2004. Environmental management indicators for ecotourism in China's nature reserves: A case study in Tianmushan Nature Reserve. Tourism Management 25(5): 559-564.

Lo, M.C., Cheuk, S. \& Atang, A. 2014. Telecentre, tourism and their impacts on Bario, Malaysia. Middle-East Journal of Scientific Research 21(6): 950-961.

Mbaiwa, J.E. \& Stronza, A.L. 2010. The effects of tourism development on rural livelihoods in the Okavango Delta, Botswana. Journal of Sustainable Tourism 18(5): 635-656.

Mbasera, M., Plessis, E.D., Saayman, M. \& Kruger, M. 2016. Environmentally-friendly practices in hotels. Acta Commercii 16(1): 1-8.

Miyakuni, K. 2012. Residents' attitudes toward tourism, focusing on ecocecentric attitudes and perceptions of economic costs: The case of Iriomote Island, Japan. Doctoral Dissertation, Michigam State University, Michigam, United States.

Mohamed, A.M.E. 2013. Actor-network theory, tourism organisations and the development of sustainable community livelihoods. Doctorate Dissertation, Plymouth University, England, United Kingdom.

Mowforth, M. \& Munt, I. 2016. Tourism and sustainability: Development, globalisation and new tourism in the third world. 4th edition. London, United Kingdom: Routledge.

Mthembu, B.M.J. 2011. Rural tourism as a mechanism for poverty alleviation in KwazuluNatal: The case of Bergville. Doctoral Dissertation, University of Zululand, KwazuluNatal, South Africa.

Munanura, I.E., Tumwesigye, B., Sabuhoro, E., Mariza, D. \& Rugerinyange, L. 2017. The quality and performance nexus of the community-based ecotourism enterprises at Nyungwe National Park, Rwanda: A total quality management perspective. Journal of Ecotourism 2(1): 1-24.

Musinguzi, D. 2012. The impacts of tourism on local communities: Developing and operationalising a comprehensive monitoring framework. Doctoral Dissertation, The Hong Kong Polytechnic University, Kowloon, Hong Kong.

Naidoo, P. \& Sharpley, R. 2016. Local perceptions of the relative contributions of enclave tourism and agritourism to community well-being: The case of Mauritius. Journal of Destination Marketing and Management 5(1): 16-25.

Nair, V., Munikrishnan, U.T., Rajaratnam, S.D. \& King, N. 2015. Redefining rural tourism in Malaysia: A conceptual perspective. Asia Pacific Journal of Tourism Research 20(3): 314337.

Nitikasetsoontorn, S. 2014. The success factors of community based tourism in Thailand. Doctoral Dissertation, National Institute of Development Administration, Bangkok, Thailand.

Okazaki, E. 2008. A community-based tourism model : Its conception and use. Journal of Sustainable Tourism 16(5): 511-529.

Osman, Z. \& Sentosa, I. 2013. Mediating effect of customer satisfaction on service quality and customer loyalty relationship in Malaysian rural tourism. International Journal of Economics Business and Management Studies 2(1): 25-37.

Ounmany, K. 2014. Community-based ecotourism in Laos: Benefits and burdens sharing among stakeholders. Doctoral Dissertation, BOKU University of Natural Resources and Life Sciences, Vienna, Austria. 
Pakurar, M. \& Olah, J. 2008. Definition of rural tourism and its characteristics in the northern great plain region. University of Debrecen, Centre for Agricultural Sciences and Engineering 7(7): 777-782.

Penrose, E.T. 1959. The Theory of the Growth of the Firm. New York, United States, Oxford University Press Inc.

Plessis, E.D., Merwe, D.V.P. \& Saayman, M. 2013. Tourists' perceptions on whether South African National Parks are environmentally friendly. Acta Academica 45(1): 187-208.

Pusiran, A.K. \& Xiao, H. 2013. Challenges and community development: A case study of homestay in Malaysia. Asian Social Science 9(5): 1-17.

Ramachandran, S. 2009. Responsible tourism: An inductive approach. Integration \& Dissemination 43: 41-50.

Rasoolimanesh, S.M., Dahalan, N. \& Jaafar, M. 2016. Tourists' perceived value and satisfaction in a community-based homestay in the Lenggong Valley World Heritage Site. Journal of Hospitality and Tourism Management 26: 72-81.

Satarat, N. 2010. Sustainable management of community-based tourism in Thailand. Doctoral Dissertation, School of Public Administration, Bangkok, Thailand.

Seers, D. 1969. The meaning of development. International Development Review 11(4): 2-6.

Sekaran, U. \& Bougie, R.J. 2016. Research Methods for Business: A Skill Building Approach. 4th edition. New York, United States: John Wiley \& Sons.

Sharpley, R. 2000. Tourism and sustainable development: Exploring the theoretical divide. Journal of Sustainable Tourism 8(1): 1-19.

Snyman, S. 2014. The impact of ecotourism employment on rural household incomes and social welfare in six southern African countries. Tourism and Hospitality Research 14(12): $37-52$.

Spenceley, A. 2005. Nature-based tourism and environmental sustainability in South Africa. Journal of Sustainable Tourism 13(2): 136-170.

State Planning Unit. 2016. Sarawak facts and figures 2015. Available at http://www.jkm.sarawak.gov.my/upload/file_folder/SPU/Sarawak $\% 20$ Facts $\% 20$ and $\% 20$ Figures\%202016.pdf

Tosun, C. 1999. Towards a typology of community participation in the tourism development process. Anatolia 10(2): 113-134.

Trihas, N., Kyriakaki, A. \& Zagkotsi, S. 2015. Local cuisine and agricultural poverty products as a means of enhancing tourists' gastronomic experiences in Greece. Proceeding on International Conference Experiential Tourism, 09-11 October, Santorini, Greece.

Truong, V.D. 2014. Tourism and poverty alleviation: A case study of Sapa, Vietnam. Doctoral Dissertation, University of Canterbury, Christchurch, New Zealand.

Truong, V.D. \& Hall, C.M. 2017. Corporate social marketing in tourism: To sleep or not to sleep with the enemy? Journal of Sustainable Tourism 25(7): 884-902.

United Nations Development Programme. 2016. Sustainable development goals. Available at http://www.undp.org/content/undp/en/home/sustainable-development-goals.html

United Nations World Tourism Organisation. 2013. UNWTO Tourism Highlights 2013 Edition. Available at http://www.e-unwto.org/doi/pdf/10.18111/9789284415427

United Nations World Tourism Organisation. 2018. UMWTO Tourism Highlights 2018 Edition. Available at http://www.e-unwto.org/doi/book/10.18111/9789284419876

United Nations. 2016. We can end poverty millennium development goals and beyond 2015. Available at http://www.un.org/millenniumgoals/poverty.shtml

Vrasti, W. 2013. Volunteer Tourism in the Global South: Giving Back in Neoliberal Times. 1st edition. United Kingdom: Routledge.

West, J. \& Haug, R. 2017. Polarised narratives and complex realities in Tanzania's southern agricultural growth corridor. Development in Practice 27(4): 418-431. 
Yamane, T. 1967. Statistics: An Introductory Analysis. 2nd edition. United States: Harper and Row.

Yoon, Y., Gursoy, D. \& Chen, J.S. 2001. Validating a tourism development theory with structural equation modelling. Tourism Management 22(4): 363-372.

Komathi Wasudawan (corresponding author)

Faculty of Business, Design and Art

Swinburne University of Technology (Sarawak Campus)

Jalan Simpang Tiga

93350 Kuching, Sarawak, MALAYSIA.

E-Mail: komathiwasu@gmail.com

Rossazana Ab-Rahim

Faculty of Economics and Business

Universiti Malaysia Sarawak

94300 Kota Samarahan, Sarawak, MALAYSIA.

E-Mail: arrossazana@unimas.my 
APPENDIX. The adapted indicators of the questionnaire and source

\begin{tabular}{|c|c|c|}
\hline \multicolumn{2}{|c|}{ Items of Rural Environment (Reflective) } & \multirow{2}{*}{$\begin{array}{l}\text { Source } \\
\text { Satarat (2010) }\end{array}$} \\
\hline RE1 & The rural environment benefits the local community. & \\
\hline RE2 & The rural environment creates conserving natural. & Mohamed (2013) \\
\hline RE3 & The rural environment creates rural tourism. & Tosun (1999) \\
\hline RE4 & The rural environment creates a natural identity (i.e., eco-tourism). & Satarat (2010) \\
\hline RE5 & $\begin{array}{l}\text { The rural environment increases flora and fauna (i.e., rafflesia, } \\
\text { orangutan, bat } \& \text { hornbill). }\end{array}$ & Musinguzi (2012) \\
\hline RE6 & $\begin{array}{l}\text { The rural environment provides recreational activities (i.e., mountain } \\
\text { climbing \& jungle trekking). }\end{array}$ & Miyakuni (2012) \\
\hline RE7 & The rural environment has a positive impact on poverty alleviation. & Satarat (2010) \\
\hline \multicolumn{2}{|c|}{ Items of Environmental Conservation (Reflective) } & Source \\
\hline $\mathrm{EC} 1$ & Environmental conservation minimises deforest by human. & Truong (2014) \\
\hline EC2 & $\begin{array}{l}\text { Environmental conservation encourages the local community to } \\
\text { participate in environmental protection. }\end{array}$ & $\begin{array}{l}\text { Faulkner and } \\
\text { Tideswell (1997) }\end{array}$ \\
\hline EC3 & $\begin{array}{l}\text { Environmental conservation increases the ability of stakeholders to } \\
\text { effectively monitor the environment. }\end{array}$ & $\begin{array}{l}\text { Faulkner and } \\
\text { Tideswell (1997) }\end{array}$ \\
\hline EC4 & $\begin{array}{l}\text { Environmental conservation prepares the regulations of governing } \\
\text { pollution control. }\end{array}$ & Miyakuni (2012) \\
\hline EC5 & $\begin{array}{l}\text { Environmental conservation contributes to the protection of flora \& } \\
\text { fauna (i.e., rafflesia, orangutan, bat \& hornbill). }\end{array}$ & Keovilay (2012) \\
\hline EC6 & $\begin{array}{l}\text { Environmental conservation provides financial, information and } \\
\text { research support to help protect the environment. }\end{array}$ & Miyakuni (2012) \\
\hline EC7 & $\begin{array}{l}\text { Environmental conservation implements waste management systems for } \\
\text { the environment. }\end{array}$ & Miyakuni (2012) \\
\hline EC8 & Environmental conservation contributes to poverty alleviation. & Satarat (2010) \\
\hline \multicolumn{2}{|c|}{ Items of Tourism Resources (Formative) } & Source \\
\hline TR1 & I employ natural resources to generate income (e.g., flora \& wildlife). & $\begin{array}{l}\text { Nitikasetsoontorn } \\
(2014)\end{array}$ \\
\hline TR2 & I conserve the natural resource (e.g., national park \& wildlife). & Truong (2014) \\
\hline TR3 & I ensure the sustainable use of natural resources. & Truong (2014) \\
\hline TR4 & I employ cultural resource to generate income. & $\begin{array}{l}\text { Nitikasetsoontorn } \\
(2014)\end{array}$ \\
\hline TR5 & I preserve the tradition, belief and cultural resource. & Truong (2014) \\
\hline TR6 & I practice the local traditional culture. & Keovilay (2012) \\
\hline TR7 & I employ rural resource to generate income. & Mthembu (2011) \\
\hline TR8 & I protect the rural resource. & Mthembu (2011) \\
\hline TR9 & I involve in maintaining rural resources. & Mthembu (2011) \\
\hline TR10 & $\begin{array}{l}\text { I employ physical resources to generate income (i.e., heritage building, } \\
\text { cave \& historical place). }\end{array}$ & $\begin{array}{l}\text { Nitikasetsoontorn } \\
(2014)\end{array}$ \\
\hline TR11 & $\begin{array}{l}\text { I protect the physical resource (i.e., heritage building, museum \& } \\
\text { historical place). }\end{array}$ & Truong (2014) \\
\hline TR12 & $\begin{array}{l}\text { I involve in maintaining the physical resource (i.e., heritage building, } \\
\text { museum \& historical place). }\end{array}$ & Miyakuni (2012) \\
\hline \multicolumn{2}{|c|}{ Items of Poverty Alleviation (Reflective) } & Source \\
\hline PA1 & Tourism development increases household income to alleviate poverty. & Keovilay (2012) \\
\hline PA2 & Tourism development creates a new tourism market to alleviate poverty. & Mthembu (2011) \\
\hline PA3 & Tourism development creates a skilled community to generate income. & Truong (2014) \\
\hline PA4 & $\begin{array}{l}\text { Tourism development adds knowledge to the community to generate } \\
\text { income. }\end{array}$ & Truong (2014) \\
\hline PA5 & $\begin{array}{l}\text { Tourism development increases infrastructure facilities for community } \\
\text { well-being. }\end{array}$ & $\begin{array}{l}\text { Faulkner and } \\
\text { Tideswell (1997) }\end{array}$ \\
\hline PA6 & $\begin{array}{l}\text { Tourism development provides access to the use of tourism resources to } \\
\text { alleviate poverty. }\end{array}$ & Mohamed (2013) \\
\hline PA7 & Tourism development decreases job insecurity. & $\begin{array}{l}\text { Yoon, Gursoy and } \\
\text { Chen }(2001)\end{array}$ \\
\hline PA8 & Tourism development creates awareness to alleviate poverty. & Truong (2014) \\
\hline PA9 & In general, tourism development has the potential to alleviate poverty. & Keovilay (2012) \\
\hline
\end{tabular}

